\begin{tabular}{lllll}
\hline LEK. SIROV. & God. XXXV & Broj 35 & Str. 151-162 & Beograd 2015. \\
LEK. SIROV. & Vol. XXXV & No. 35 & Pp. 151-162 & Belgrade 2015. \\
\hline
\end{tabular}

Originalni naučni rad - Original scientific paper

Rukopis primljen: 4.12.2015.

UDC: 665.528.279.41; 615.322:582.794.1 Prihvaćen za publikovanje: 14.12.2015.

COBISS.SR-ID 220256012

\title{
SUSCEPTIBILITY OF ORAL CANDIDA SPP. REFERENCE STRAINS AND CLINICAL ISOLATES TO SELECTED ESSENTIAL OILS OF APIACEAE SPECIES
}

\section{Miloš Nikolić ${ }^{1}$, Tatjana Markovic ${ }^{2}$, Ana Ćirić ${ }^{1}$ Jasmina Glamočlija $^{1}$, Dejan Marković ${ }^{3}$, Marina Soković ${ }^{1}$}

${ }^{1}$ Institute for Biological Research "Siniša Stanković", University of Belgrade, Bulevar Despota Stefana 142, 11000 Belgrade, Serbia

2 Institute for Medicinal Plant Research "dr Josif Pančić", Tadeuša Košćuška 2, 11000 Belgrade, Serbia

${ }^{3}$ Faculty of Dental Medicine, Department of Pediatric and Preventive Dentistry, University of Belgrade, dr Subotića 8, 11000 Belgrade, Serbia

\section{SUMMARY}

The aim of this study was to investigate the chemical composition and antifungal activity of four essential oils from Apiaceae family, Pastinaca sativa, Foeniculum vulgare, Pimpinella anisum and Anethum graveolens, against Candida spp. reference strains and clinical isolates from human oral cavities. Chemical analysis of the essential oils (GCFID and GC/MS) showed that predominating chemical classes in the essential oil of A. graveolens was monoterpene hydrocarbons (49.4\%) and the major constituent of the oil was carvone (42.2\%): while in the oils of $P$. anisum, $F$. vulgare and $P$. sativa majority of compounds belong to phenylpropenes $(80.9 \%, 65.9 \%$ and $49.4 \%$, respectively): and the major oil constituents were trans-anethole $(65.1 \%$ and $80.8 \%)$ and myristicine (49.0\%): respectively. Minimum inhibitory (MIC) and minimum fungicidal (MFC) concentrations were determined using microdilution method. All the tested oils inhibited growth of Candida spp. The strongest antifungal activity was shown by $A$. graveolens essential oil (MIC 0.63-2.5 mg mL${ }^{-1}$; MFC 1.25-5 mg mL ${ }^{-1}$ ). In addition to the common use of parsnip, fennel, anise and dill in traditional medicine, present study validates use of their essential oils in treatments intended for reduction and elimination of Candida spp. population in human patients with fungal infection.

Keywords: Apiaceae, essential oils, Candida spp., antifungal activity. 


\section{INTRODUCTION}

The genus Candida forms a part of the normal oral microbiota. C. albicans is an opportunistic pathogen and a major causative agent of superficial as well as life treating dissemination infections [1]. Besides C. albicans, other Candida species, such as C. krusei, C. tropicalis, C. parapsilopsis, C. dubleniensis are even more frequently isolated as a consequence of invasive treatments in immunocompromised patients and use of wide spectrum antibiotics [2]. Currently available synthetic drugs intended for treatment of fungal infections, Fluconazole and Nystatin, bring about challenge such as development of resistant strains and thus limited clinical effectiveness [3]. These impose necessity to find out safer and more efficient antifungal agent for proper management and treatment of Candida related infections.

Interest in therapeutic use of non-conventional, non-prescription, or socalled natural medicines in the field of infectious diseases increased remarkably in recent years. Plants present valuable sources of new bioactive compounds, mostly driven by the well-known side effects of conventional drugs as well as by the spread of antimicrobial resistance to otherwise efficient and well-tolerated drugs [4].

Apiaceae (Umbilliferae) family comprises more than 3700 speciesspread across 455 genera [5]. This family includes well known plants such as: anise, carrot, dill, fennel, parsley, parsnip, celery etc. Plants from Apiaceae family are known as condiments due to their flavor, and are also appreciated in perfumery and medicine [6]. They have been used as household remedies against digestive, gynecologic, neurologic, respiratory and gastrointestinal disorders (e.g. indigestion, flatulence, colic pain etc.): and their dry ripe fruits and essential oils have aromatic, carminative, stomachic and diuretic properties [7]. The essential oils (EO) of these plants have been also reported to possess antimicrobial activity [8-11].

The objective of this study was to evaluate chemical composition and determine minimum inhibitory and minimum fungicidal concentrations of four essential oils belonging to Apiaceae family, Pastinaca sativa, Foeniculum vulgare,

Pimpinella anisum and Anethum graveolens, against reference and oral Candida spp. clinical isolates. The results were compared with positive control, Nystatin.

\section{MATERIAL AND METHODS}

\section{Essential oils}

Four essential oils (EOs) from Apiaceae family were used in this experiment. The seed oils from Foeniculum vulgare, Pimpinella anisum and Anethum graveolens were purchased from Herbal Pharmacy of the Institute for Medicinal Plants "Dr Josif Pančić" Belgrade, Serbia, while the root oil from 
Pastinaca sativa was extracted in the laboratory, according to following procedure: dried root of $P$. sativa was ground to a powder $(300 \mathrm{~g})$ : and subjected to distillation for 3 hours using a Clevenger-type apparatus. The crude oil was dried over anhydrous sodium sulphate to remove remaining water. All essential oils were kept in a refrigerator at $4^{\circ} \mathrm{C}$, in the dark, until used in this experiment.

\section{Essential oils isolation and analyses procedure}

The procedure used for Gas Chromatography coupled with a FlameIonization Detector (GC-FID) and Gas Chromatography / Mass Spectrometry (GC/MS) analyses complies with standards set for gas chromatography of essential oils (ISO 7609:1985; ISO11024 -1:1998, and 11024 -2:1998).

GC-FID analysis was performed using a GC Agilent Technologies 7890 Apparatus, equipped with the split-splitless injector and automatic liquid sampler (ALS): attached to HP-5 column $(30 \mathrm{~m} \times 0.32 \mathrm{~mm}$, film thickness $0.25 \mu \mathrm{m})$ and fitted with aflame-ionization detector (FID). Operating conditions were as follows: carrier gas was $\mathrm{H} 2\left(1 \mathrm{ml} / \mathrm{min} / 210{ }^{\circ} \mathrm{C}\right)$; temperatures of injector and detector were set at $250{ }^{\circ} \mathrm{C}$ and $280{ }^{\circ} \mathrm{C}$, respectively, while the column temperature was linearly programmed $40-260^{\circ} \mathrm{C}$ at $4^{\circ} \mathrm{C} / \mathrm{min}$.

Solutions of $F$. vulgare, $P$. anisum and A. graveolens essential oils' samples in ethanol and $P$. sativa oil sample in petroleum ether (approx. 1\%) were consecutively injected by ALS ( $1 \mu \mathrm{l}$, split-mode).The percentile presence of components in essential oils' samples were calculated from the peak areas obtained in the area-percent reports (obtained as a result of standard processing of chromatograms) without correction factors, using normalization method.

The GC/MS was performed on an HP G1800C Series II GCD analytical system equipped with an HP-5MS column $(30 \mathrm{~m} \times 0.25 \mathrm{~mm}$, film thickness 0.25 $\mu \mathrm{m})$. The carrier gas was $\mathrm{He}(1 \mathrm{ml} / \mathrm{min})$. Other chromatographic conditions were the same as those for GC-FID. The transfer line was heated at $260^{\circ} \mathrm{C}$. Mass spectra were recorded in EI mode $(70 \mathrm{eV})$ : in a range of $\mathrm{m} / \mathrm{z} 40-450$. Solutions of $F$. vulgare, $P$. anisum and A. graveolens essential oils' samples in ethanol and $P$. sativa oil sample in petroleum (approx. 1\%) were consecutively injected by ALS $(0.2 \mu 1$, split mode).

The identification of essential oils components was based on matching of their mass spectra peaks with those from the Wiley 275 and NIST/NBS libraries. The experimental values for Kovats' retention indices (RI) were determined by using calibrated Automated

Mass Spectral Deconvolution and Identification System software (AMDIS ver. 2.1.): compared to those from available literature [12], and they were used asadditional tools to support the MS findings. 


\section{Microorganisms}

In this study, fifty four clinical isolates of Candida spp.and two ATCC strainswere used of (Candida albicansATCC 10231 and Candida tropicalis ATCC 750). Reference strains were obtained from the Laboratory for Mycology at the Institute for Biological Research "Siniša Stanković" University of Belgrade, Serbia. All clinical isolates were obtained by rubbing sterile cotton swabs over oral mucosa from randomly chosen patients at the Department of Pediatric and Preventive Dentistry, Faculty of Dental Medicine, University of Belgrade, Serbia. The swabs were transferred to SD broth medium for Candida and thoroughly mixed using vortex mixer and $50 \mu \mathrm{l}$ of suspension inoculated on various selective and non-selective medium and incubated microaerobically for $48 \mathrm{~h}$ at $37^{\circ} \mathrm{C}$. Isolates were identified using biochemical profiles with API 20C (bioMérieux France) and Chrom-Agar (Liofilchems.r.l. Italy).

\section{Antifungal activity}

Minimum inhibitory (MIC) and minimum fungicidal (MFC) concentrations were determined by microdilutiom method in 96 well microtitre plates [13]. Briefly, fresh overnight cultures of yeasts were adjusted with sterile saline to a concentration of $1.0 \times 10^{5} \mathrm{CFU} /$ per well. The microplates were incubated for $24 \mathrm{~h}$ at $37^{\circ} \mathrm{C}$. The MIC of the samples was detected following addition of $40 \mu \mathrm{l}$ of PIodonitrotetrazolium violet (INT) $0.2 \mathrm{mg} \mathrm{mL}^{-1}$ (Sigma I8377) and incubation at $37^{\circ} \mathrm{C}$ for $30 \mathrm{~min}$. The MIC was considered as a lowest concentration with no visible growth detected under microscope. The MFCs were determined by serial subcultivation of $10 \mu \mathrm{l}$ into microtitre plates containing $100 \mu \mathrm{l}$ of broth per well and further incubation for $24 \mathrm{~h}$ at $37^{\circ} \mathrm{C}$. The lowest concentration with no visible growth was defined as MFC, indicating $99.5 \%$ killing of an original inoculum. Nystatin (Hemofarm, Serbia) was used as a positive control.

\section{RESULTS AND DISCUSSION}

Chemical composition of investigated Apiaceae family essential oils is presented in Table 1.

The hydrodistillation of $P$. sativadry roots yielded $0.16 \%(\mathrm{w} / \mathrm{w})$ of essential oil. The oil proved to be almost equally rich in phenylpropenes and monoterpene hydrocarbons, which together accounted for $97,7 \%$ of the total oil content. The major oil constituents were myristicine $(49.0 \%)$ and terpinolene (39.8\%): as also reported in another study [14], though the contents of those two constituents quite differed. Similarly to $P$. sativa, the EOs from $P$. anisum and $F$. vulgare were abundant in phelypropenes ( $80.8 \%$ and $65.1 \%$, respectively); the major constituent of both oils was trans-anethole. 
Table 1. Chemical composition of four tested essential oils from Apiaceae family. Tabela 1. Hemijski sastav ispitivana četri etarska ulja iz familije Apiaceae.

\begin{tabular}{|c|c|c|c|c|c|c|}
\hline & Essential oil & RI* & Con & ribution to & the oil & o m/m) \\
\hline & constituents & & F. vulgare & P. anisum & $P$. sativa & A. graveolens \\
\hline 1 & Tricyclene & 918 & & & 0.1 & 0.1 \\
\hline 2 & Thujene $<$ alpha- $>$ & 923 & & 0.6 & 0.4 & 0.6 \\
\hline 3 & Pinene $<$ alpha- $>$ & 924 & 1.5 & & & \\
\hline 4 & Camphene & 938 & 0.2 & & & \\
\hline 5 & Sabinene & 966 & $\operatorname{tr}$ & & 3.2 & \\
\hline 6 & Pinene $<$ beta- $>$ & 967 & 0.1 & & & \\
\hline 7 & Myrcene & 983 & $\operatorname{tr}$ & & 0.7 & 0.4 \\
\hline 8 & Phellandrene $<$ alpha- $>$ & 995 & 0.4 & & 0.4 & 14.2 \\
\hline 9 & Caren $<$ delta-3- $>$ & 1003 & $\operatorname{tr}$ & & & \\
\hline 10 & Terpinene $<$ alpha- $>$ & 1008 & & & 0.1 & \\
\hline 11 & Cymene $<$ para- $>$ & 1016 & 0.3 & & 0.1 & 2.0 \\
\hline 12 & Limonene & 1020 & 1.3 & & 2.0 & 32.0 \\
\hline 13 & Cineol $<1,8->$ & 1023 & 0.2 & 4.7 & & \\
\hline 14 & Ocimene $<$ cis-beta- $>$ & 1031 & & & 0.7 & \\
\hline 15 & Ocimene $<$ trans-beta- $>$ & 1041 & & & 0.2 & \\
\hline 16 & Terpinene $<$ gamma- $>$ & 1050 & 0.3 & & 0.2 & \\
\hline 17 & Fenchone & 1080 & 25.6 & & & \\
\hline 18 & Terpinolene & 1086 & & & 39.8 & \\
\hline 19 & Linalool & 1096 & & 1.5 & & \\
\hline 20 & Menthatriene $<1,3,8$-para- $>$ & 1103 & & & 0.2 & \\
\hline 21 & Ocimene $<$ allo- $>$ & 1123 & & & 0.3 & \\
\hline 22 & Thujanol<iso-3-> & 1130 & & & 0.1 & \\
\hline 23 & Camphor & 1135 & 0.7 & & & \\
\hline 24 & Menthone & 1146 & & & & 0.4 \\
\hline 25 & Menthone $<$ iso- $>$ & 1156 & & & & 0.2 \\
\hline 26 & Menthol $<$ neo- $>$ & 1166 & & & & 0.3 \\
\hline 27 & Terpinene-4-ol & 1169 & & 0.6 & 0.1 & \\
\hline 28 & Dill ether & 1176 & & & & 6.7 \\
\hline 29 & Cymen-8-ol<para-> & 1178 & & & 0.9 & \\
\hline 30 & Terpineol $<$ alpha- $>$ & 1186 & & 0.8 & & \\
\hline 31 & Dihydrocarvone $<$ cis- $>$ & 1189 & & & & 1.3 \\
\hline 32 & Methyl chavicol & 1192 & 3.4 & 6.3 & & \\
\hline 33 & Dihydrocarvone $<$ trans- $>$ & 1196 & & & & 1.0 \\
\hline 34 & Dihydrocarveol<iso-> & 1210 & & & & 0.1 \\
\hline 35 & Verbenyl acetate $<$ cis- $>$ & 1217 & & & 0.1 & \\
\hline 36 & Dihydrocarveol< $<$ neoiso-> & 1223 & & & & 0.3 \\
\hline 37 & Carvone & 1238 & & & & 40.2 \\
\hline 38 & Anethole $<$ cis- $>$ & 1247 & 0.8 & 0.1 & & \\
\hline 39 & Anethole $<$ trans- $>$ & 1283 & 65.1 & 80.8 & & \\
\hline 40 & Verbenyl acetate $<$ trans- $>$ & 1291 & & & 0.1 & \\
\hline 41 & Copaene $<$ alpha- $>$ & 1366 & & 0.7 & & \\
\hline 42 & Anisyl methyl ketone & 1390 & & 1.9 & & \\
\hline 43 & Longipinene $<$ beta- $>$ & 1396 & & 0.2 & & \\
\hline 44 & Caryophyllene $<$ cis-beta-> & 1407 & & & 0.1 & \\
\hline
\end{tabular}




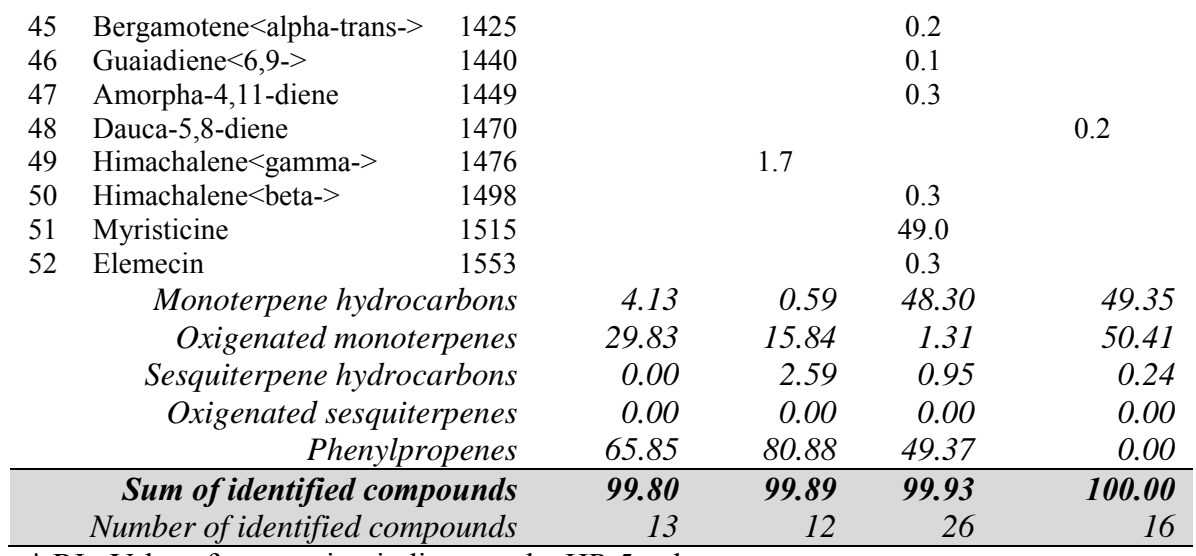

* RI -Values for retention indices on the HP-5 column.

Earlier studies also confirmed the abundance of trans-anethole in both oils [15] as well as a great variability in its content $[16,17]$. In addition, analysis of both EOs also revealed a high content of oxygenated monoterpenes, but the major difference between them was in contents of mono and sesqiterpene hydrocarbon oil portions. The result of analysisof our A. graveolens EO is in consistency to another study [18]. In addition, the oil revealed quite differing composition comparing to the remaining three Apiaceae oils. The two main EO classes, monoterpene hydrocarbons and oxygenated monoterpenes, contributed to the oil in almost equal quantities, together representing $99,8 \%$ of the total oil; the major constituents proved to be cis-anethole (40,2\%): limonene $(32,0 \%)$ and phellandrene $(14.2 \%)$.

The results of antifungal activity of selected EOs are presented in Table 2. Compared to the positive control with Nystatin (MIC 0.01- $0.5 \mathrm{mg} \mathrm{mL}^{-1}$; MFC 0.01$1 \mathrm{mg} \mathrm{mL}{ }^{-1}$ ), neither of the tested EOs expressed stronger antifungal activity. The strongest average antifungal activity was achieved by $A$. graveolens oil, as well as $P$. sativa (MIC $0.63-1.25 \mathrm{mg} \mathrm{mL}^{-1}$; MFC $1.25-5 \mathrm{mg} \mathrm{mL}^{-1}$ ) while the oils of $P$. anisum and $F$. vulgare inhibited growth of all tested fungi in the range of MIC 1.25-2.5 and $1.25-5 \mathrm{mg} \mathrm{mL}^{-1}$, respectively, and MFC $2.5-5.0$ and $2.5-10 \mathrm{mg} \mathrm{mL}^{-1}$, respectively.

There are many reports of antimicrobial effect of Apiaceae family EOs, related to medically significant bacteria and fungi [19]. However, limited data exist regarding the activity against clinical specimens, particularly $C$. krusei and $C$. glabrata. In our study, in comparison C. albicans whose clinical isolates expressed great variability in their susceptibility to tested Apiace EOs (MIC 0.63-5.0 and MFC $1.25-10 \mathrm{mg} \mathrm{mL}^{-1}$ ): clinical isolates of $C$. krusei (MIC 0.63-2.5 and MFC 1.25-5.0 mg $\mathrm{mL}^{-1}$ ) and C. glabrata (MIC 1.25-5 and MFC 2.5-5 mg mL ${ }^{-1}$ ): in general, both proved to be lass variable in their response to tested EOs. 
Table 2. Antifungal activity of four essential oils from Apiaceae family $\left(\mathrm{mg} \mathrm{mL}^{-1}\right)$ Tabela 2. Antifungalna aktivnost četri etarska ulja iz familije Apiaceae $\left(\mathrm{mg} \mathrm{mL}^{-1}\right)$

\begin{tabular}{|c|c|c|c|c|c|c|c|c|c|c|}
\hline \multirow{3}{*}{$\begin{array}{l}\text { Candida spp. } \\
\text { reference } \\
\text { strains and } \\
\text { clinical isolates }\end{array}$} & \multicolumn{8}{|c|}{ Essential oils } & \multirow{2}{*}{\multicolumn{2}{|c|}{$\begin{array}{l}\text { Control } \\
\text { Nystatin }\end{array}$}} \\
\hline & \multicolumn{2}{|c|}{ P. sativa } & \multicolumn{2}{|c|}{ F. vulgare } & \multicolumn{2}{|c|}{ P. anis } & \multicolumn{2}{|c|}{ A. graveolens } & & \\
\hline & MIC & MFC & MIC & MFC & MIC & MFC & MIC & MFC & MIC & MFC \\
\hline 1 C.a. clin. & 2.5 & 5 & 2.5 & 5 & 2.5 & 5 & 1.25 & 2.5 & 0.01 & 0.03 \\
\hline 2 C. krusei clin. & 2.5 & 5 & 2.5 & 5 & 2.5 & 5 & 1.25 & 2.5 & 0.01 & 0.03 \\
\hline 3 C.a. clin. & 2.5 & 5 & 2.5 & 5 & 2.5 & 5 & 1.25 & 2.5 & 0.007 & 0.01 \\
\hline 4 C.a. clin. & 2.5 & 5 & 2.5 & 5 & 2.5 & 5 & 1.25 & 2.5 & 0.007 & 0.01 \\
\hline 5 C.a. clin. & 2.5 & 5 & 2.5 & 5 & 2.5 & 5 & 1.25 & 2.5 & 0.007 & 0.01 \\
\hline 6 C.a. clin. & 2.5 & 5 & 2.5 & 5 & 2.5 & 5 & 1.25 & 2.5 & 0.007 & 0.01 \\
\hline 7 C.a. clin. & 2.5 & 5 & 2.5 & 5 & 1.25 & 2.5 & 1.25 & 2.5 & 0.007 & 0.01 \\
\hline 8 C.a. clin. & 2.5 & 5 & 2.5 & 5 & 2.5 & 5 & 1.25 & 2.5 & 0.007 & 0.01 \\
\hline 9 C.a. clin. & 2.5 & 5 & 2.5 & 5 & 1.25 & 2.5 & 1.25 & 2.5 & 0.007 & 0.01 \\
\hline 10 C. k. clin. & 1.25 & 5 & 2.5 & 5 & 1.25 & 2.5 & 0.63 & 1.25 & 0.01 & 0.03 \\
\hline 11 C.a. clin. & 2.5 & 5 & 2.5 & 5 & 2.5 & 5 & 1.25 & 2.5 & 0.007 & 0.01 \\
\hline 12 C.a. clin. & 2.5 & 5 & 2.5 & 5 & 2.5 & 5 & 1.25 & 2.5 & 0.01 & 0.03 \\
\hline 13 C.a. clin. & 2.5 & 5 & 2.5 & 5 & 1.25 & 2.5 & 1.25 & 2.5 & 0.01 & 0.03 \\
\hline 14 C.a. clin. & 2.5 & 5 & 2.5 & 5 & 2.5 & 5 & 1.25 & 2.5 & 0.01 & 0.03 \\
\hline 15 C.a. clin. & 2.5 & 5 & 2.5 & 5 & 2.5 & 5 & 1.25 & 2.5 & 0.007 & 0.01 \\
\hline 16 C.a. clin. & 2.5 & 5 & 2.5 & 5 & 2.5 & 5 & 1.25 & 2.5 & 0.01 & 0.03 \\
\hline 17 C.a. clin. & 2.5 & 5 & 2.5 & 5 & 2.5 & 5 & 1.25 & 2.5 & 0.007 & 0.01 \\
\hline 18 C.a. clin. & 2.5 & 5 & 2.5 & 5 & 2.5 & 5 & 1.25 & 2.5 & 0.007 & 0.01 \\
\hline 19 C.a. clin. & 2.5 & 5 & 2.5 & 5 & 2.5 & 5 & 1.25 & 2.5 & 0.007 & 0.01 \\
\hline 20 C. g. clin. & 1.25 & 5 & 2.5 & 5 & 2.5 & 5 & 1.25 & 2.5 & 0.007 & 0.01 \\
\hline 21 C.a. clin. & 1.25 & 5 & 2.5 & 5 & 1.25 & 2.5 & 0.63 & 1.25 & 0.007 & 0.01 \\
\hline 22 C.a. clin. & 2.5 & 5 & 2.5 & 5 & 2.5 & 5 & 1.25 & 2.5 & 0.007 & 0.01 \\
\hline 23 C.a. clin. & 2.5 & 5 & 2.5 & 5 & 2.5 & 5 & 1.25 & 2.5 & 0.007 & 0.01 \\
\hline 24 C.a. clin. & 2.5 & 5 & 2.5 & 5 & 1.25 & 2.5 & 1.25 & 2.5 & 0.007 & 0.01 \\
\hline 25 C.a. clin. & 2.5 & 5 & 2.5 & 5 & 2.5 & 5 & 1.25 & 2.5 & 0.03 & 0.06 \\
\hline 26 C.a. clin. & 2.5 & 5 & 2.5 & 5 & 2.5 & 5 & 1.25 & 2.5 & 0.007 & 0.01 \\
\hline 27 C. g. clin. & 2.5 & 5 & 2.5 & 5 & 2.5 & 5 & 1.25 & 2.5 & 0.007 & 0.01 \\
\hline 28 C.a. clin. & 2.5 & 5 & 2.5 & 5 & 2.5 & 5 & 1.25 & 2.5 & 0.01 & 0.03 \\
\hline 29 C.a. clin. & 2.5 & 5 & 2.5 & 5 & 2.5 & 5 & 1.25 & 2.5 & 0.007 & 0.01 \\
\hline 30 C.a. clin. & 2.5 & 5 & 5 & 5 & 2.5 & 5 & 1.25 & 2.5 & 0.007 & 0.01 \\
\hline 31 C.a. clin. & 2.5 & 5 & 2.5 & 5 & 1.25 & 2.5 & 0.63 & 1.25 & 0.007 & 0.01 \\
\hline 32 C.a. clin. & 2.5 & 5 & 2.5 & 5 & 2.5 & 5 & 1.25 & 2.5 & 0.01 & 0.03 \\
\hline 33 C.a. clin. & 1.25 & 2.5 & 2.5 & 5 & 2.5 & 5 & 0.63 & 1.25 & 0.5 & 1 \\
\hline 34 C.a. clin. & 2.5 & 5 & 2.5 & 5 & 2.5 & 5 & 1.25 & 2.5 & 0.007 & 0.01 \\
\hline 35 C.a. clin. & 2.5 & 5 & 2.5 & 5 & 2.5 & 5 & 1.25 & 2.5 & 0.007 & 0.01 \\
\hline 36 C.a. clin. & 2.5 & 5 & 1.25 & 2.5 & 1.25 & 2.5 & 2.5 & 5 & 0.007 & 0.01 \\
\hline 37 C.a. clin. & 2.5 & 5 & 5 & 10 & 2.5 & 5 & 2.5 & 5 & 0.007 & 0.01 \\
\hline 38 C.a. clin. & 2.5 & 5 & 5 & 10 & 2.5 & 5 & 1.25 & 2.5 & 0.03 & 0.06 \\
\hline
\end{tabular}




\begin{tabular}{lcccccccccc} 
39 C.a. clin. & 2.5 & 5 & 5 & 10 & 2.5 & 5 & 1.25 & 2.5 & 0.007 & 0.01 \\
40 C.a. clin. & 2.5 & 5 & 5 & 10 & 1.25 & 2.5 & 1.25 & 2.5 & 0.007 & 0.01 \\
41 C.a. clin. & 2.5 & 5 & 2.5 & 5 & 2.5 & 5 & 1.25 & 2.5 & 0.007 & 0.01 \\
42 C.a. clin. & 1.25 & 2.5 & 1.25 & 2.5 & 2.5 & 5 & 0.63 & 1.25 & 0.007 & 0.01 \\
43 C.a. clin. & 2.5 & 5 & 2.5 & 5 & 2.5 & 5 & 1.25 & 2.5 & 0.007 & 0.01 \\
44 C.a. clin. & 1.25 & 2.5 & 1.25 & 2.5 & 2.5 & 5 & 1.25 & 2.5 & 0.007 & 0.01 \\
45 ATCC10231 & 1.25 & 2.5 & 2.5 & 5 & 2.5 & 5 & 1.25 & 2.5 & 0.007 & 0.01 \\
46 ATCC750 & 0.625 & 1.25 & 2.5 & 5 & 2.5 & 5 & 1.25 & 2.5 & 0.007 & 0.01 \\
47 C.a. clin. & 1.25 & 2.5 & 2.5 & 5 & 2.5 & 5 & 0.63 & 1.25 & 0.007 & 0.01 \\
48 C.a. clin. & 1.25 & 2.5 & 2.5 & 5 & 2.5 & 5 & 0.63 & 1.25 & 0.007 & 0.01 \\
49 C.a. clin. & 2.5 & 5 & 2.5 & 5 & 2.5 & 5 & 1.25 & 2.5 & 0.007 & 0.01 \\
50 C.a. clin. & 2.5 & 5 & 2.5 & 5 & 2.5 & 5 & 1.25 & 2.5 & 0.007 & 0.01 \\
51 C.a. clin. & 2.5 & 5 & 2.5 & 5 & 2.5 & 5 & 0.63 & 1.25 & 0.01 & 0.03 \\
52 C.a. clin. & 2.5 & 5 & 2.5 & 5 & 2.5 & 5 & 1.25 & 2.5 & 0.007 & 0.01 \\
53 C.a. clin. & 2.5 & 5 & 2.5 & 5 & 2.5 & 5 & 1.25 & 2.5 & 0.007 & 0.01 \\
54 C.a. clin. & 2.5 & 5 & 2.5 & 5 & 2.5 & 5 & 1.25 & 2.5 & 0.01 & 0.03 \\
55 C.a. clin. & 2.5 & 5 & 5 & 10 & 2.5 & 5 & 1.25 & 2.5 & 0.007 & 0.01 \\
56 C.a. clin. & 2.5 & 5 & 2.5 & 5 & 2.5 & 5 & 1.25 & 2.5 & 0.007 & 0.01 \\
\hline C.a. clin. - C. albicans clinical isolate; C.k. clin.-C. krusei clinical isolate; C.g. clin.-C. \\
glabrata clinical isolate; ATCC (The American Type Culture Collection); ATCC10231- \\
C. albicans; ATCC750-C. tropicalis.
\end{tabular}

In addition, in the present study, no great differences in their response to the tested Apiace EOs were observed between the tested clinical isolates and the reference Candida spp. strains. Regarding the general susceptibility to Apaceae EOs, clinical isolates of C. krusei and C. glabrata, in comparison to C. albicans, seemed to be more and less susceptible, respectively (Table 2).

In the present study, all the tested microorganisms were inhibited by selected essential oils to a certain extent. Previous research on antifungal activity of $F$. vulgare, $P$. anisum, $P$. sativa and A. graveolens essential oils showed that they possess a specific activity [20-22]. However, due to different test methods applied, in addition to different fungal strains and sources of antimicrobial samples, the results from different studies are not directly comparable with ours. Similarly to our other study [23], in the present study, the oil of A. graveolens with its highest contents of both, monoterpene hydrocarbons and oxigenated monoterpenes, comparing to other three EOs (Table 1): was the most efficient oil against almost all fungi. The exception was ATCC single strain of $C$. tropicalis that proved to be the most susceptible to $P$. sativa oil, followed by the oil of A. graveolens; the both oils are rich in monoterpene hydrocarbons, while the oils of $P$. anisum and $F$. vulgare, that generally expressed lower antifungal activity, are poor in this class of compounds.

Plant EOs have been used in folk medicine for many years. Among them, due to their antimicrobial activity against a wide range of pathogenic 
microorganisms, EOs from Apiaceae species attracted a huge interest. Nowadays, the resistance of human pathogens to multiple drugs is well known and it indicates the urge to search for novel antimicrobial substances; plants represent a huge source of natural compounds with various biological activities and desirable therapeutic properties.

During the last two decades, the yeasts of the genus Candida have received a great attention in medical literature. Use of herbs and its products for various health problems, as an alternative to the standard drugs, is prevailing in developing countries and already well established in some cultures and traditions. With regard to the mentioned raising trend, our results seem to be very encouraging. They prove that tested secondary metabolites (essential oils) extracted from aromatic plants of Apiaceae family possess natural antifungal potential; among the tested EOs, the oil from A. graveolens was the strongest one against all tested clinical isolates. As it is explained, its efficacy seems to be directly linked to its chemical composition (high portion of monoterpenes). However, use of the entire EOs does not allow determination of single active principles, and some studies shows that oils in its complete composition express a greater antimicrobial activity than their single components, suggesting a great meaning of synergistic effect of the oil's minor and major constituents [24].

Although in comparison to Apiaceae EOs tested in our study Nystatin showed stronger antifungal activity, it is well known that synthetic drugs may cause certain adverse effects, such as toxicity, allergic reactions, and possibly lead to the emergence of resistance after a certain period of use, particularly in patients with recurrent infections with Candida. In addition, antifungal and therapeutic potential of herbal essential oils and their components are known for their in vitro and in vivo efficacy, with no harmful effects [25].

Development of resistance to synthetic drugs poses a serious long-term threat to the public health. This work suggests essential oils as naturally occurring antimicrobial agents that could be used in formulations of a novel, promising drug intended for use in treatment and prevention of Candida-related infections. Further and more detailed studies are required prior to their application in the regular clinical dental practice.

\section{ACKNOWLEDGMENTS}

The authors are grateful to the Ministry of Education, Science and Technological Development of Serbia for financial support (Grants № 173032). 


\section{REFERENCES}

1. Drogari-Aparianthitou M., Mantoplulou F.D., Skiada A., Kanioura L., Grammatikou M. Vrioni G., Mitroussia-Ziouva A., Tsakris A., Petrikkos G. (2003): In vitro susceptibility testing of filamentous fungi: comparison of E-test and reference M38-A microdilution methods for determining posaconazole MICs. Diagn Microbiol Infect Dis, 45: 241-244.

2. Meurman J.H., Siikala E., Richardson M., Rautemaa R. (2007): Non-Candida albicans Candida yeasts of the oral cavity. In: Communicating Current Research and Educational Topics and Trends in Applied Microbiology. Microbiology Book series (Eds. A. Méndez-Vilas): 719-731. Formatex Research Center, Badajoz, Spain.

3. Sheehan D.J., Hitchcock C.A., Sibley C.M. (1999): Current and emerging azole antifungal agents. Clin Microbiol Rev, 12: 40-79.

4. Carson C.F., Riley T.V. (1993): Antimicrobial activity of essential oil of Melaleuca alternifolia. J Appl Microbiol, 16: 49-55.

5. Mohammadreza V. (2008): Chemical composition and antimicrobial activity of Pimpinella affinis Ledeb essential oil growing in Iran. Int J Green Pharm, 2:13840.

6. Santos P.M., Figueiredo A.C., Oliveira M.M., Barroso J.G., Pedro L.G., Deans S.G., Younus A.K.M. , Scheffer J.J.C. (1998): Essential oils from hairy root cultures and from fruits and roots of Pimpinella anisum. Phytochemistry, 46: 455460.

7. Kaur, G.J., Arora D.S. (2009): Antibacterial and phytochemical screening of Anethum graveolens, Foeniculum vulgare and Trachyspermum ammi. BMC Complement Altern Med, 9, 30.

8. Gülçin I, Oktay M, Kireçci E, Kufrevioglu I. (2003): Screening of antioxidant and antimicrobial activities of anise (Pimpinella anisum L.) seed extracts. Food Chem. 83: 371-382.

9. Brkovic D. L., Comic L. J., Solujic-Sukdolak S. (2006): Antibacterial activity of some plants from family Apiaceae in relation to selected phytopathogenic bacteria. Krag J Sci, 28: 65-72.

10. Gulfraz M., Mehmood S, Minhas N., Jabeen N., Kausa, R., Jabeen K., Arshad, G. (2008): Composition and antimicrobial properties of essential oil of Foeniculum vulgare. Afr J Biotechnol, 7: 4364-4368.

11. Stojković S., Petrović S., Kukić J., Džamić A., Ristić M., Milenković M., Glamočlija J., Soković M., Stojković D. (2009): Chemical composition and antimicrobial and antioxidant activity of Seseli rigidum flower essential oil. Chem Nat Compd, 45: 253-256.

12. Adams R.P. (2007): Identification of Essential Oil Component by Gas Chromatography/Mass Spectrometry. Allured Publishing, Carol Stream, IL, USA. 
13. Douk K.D., Dagher M.S., Sattout J.E. (1995): Antifungal activity of the essential oil of Origanum syriacum L. J Food Prot, 58: 1147-1149.

14. Stahl, E. and K.H. Kubeczka (1979): Überätherische Öle der Apiaceae (Umbelliferae). VI. Untersuchungen zum Vorkommen von Chemotypen bei Pastinaca sativa L. Planta Med, 37: 49-56.

15. Gende L.B., Maggi M.D., Fritz R., Eguaras M.J. (2009): Antimicrobial activity of Pimpinella anisum and Foeniculum vulgareessential oils against Paenibacillus larvae subsp. larvae. J Essent Oil Res, 21: 91-93.

16. Miguel M.G., Cruz C., Faleiro L. Simoes M.T., Fiqueiredo A.C. Barroso J.G.,. Pedro L.G . (2010): Foeniculum vulgare essential oils: chemical composition, antioxidant and antimicrobial activities. Nat Prod Commun, 5: 319-28.

17. Orav A., Raal A., Arak E. (2008): Essential oil composition of Pimpinella anisum L. fruits from various European countries. Nat Prod Res, 22: 227-232.

18. Jirovetz L., Buchbauer G.., Stoyanova A.S., Geogriev E.V., Damianova S.T. (2003): Composition, quality control and antimicrobial activity of the essential oil of long-time stored dill (Anethum graveolens L.) seeds from Bulgaria. J Agr Food Chem, 51: 3854-3857.

19. Orhan İ.E., Özcelik B., Kartal M., Kan Y. (2012): Antimicrobial and antiviral effects of essential oils from selected Umbelliferae and Labiatae plants and individual essential oil components. Turk J Biol, 36: 239-246.

20. Manzoor A.R., Bilal A.D., Shahnawaz N.S., Bhat B.A., Quirishi M.A. (2012): Foeniculum vulgare: A comprehensive review of its traditional use, phytochemistry, pharmacology, and safety. Arab J Chem http://dx.doi.org/10.1016/j.arabjc.2012.04.011

21. Shojaii, A., Fard M.A. (2012): Review of pharmacological properties and chemical constituents of Pimpinella anisum. ISRN Pharm. http://dx.doi.org/10.5402/2012/510795

22. Singh G., Maurya S., De-Lampasona M.P., Catalan C. (2005): Chemical constituents, antimicrobial investigations and antioxidant potentials of Anethum graveolens L. essential oil and acetone extract: Part 52. J Food Sci,70: M208-215.

23. Nikolić M., Glamočlija J., Ferreira C.F.R.I., Calhelh, C.R., Fernandes A., Marković T., Marković D., Giweli A., Soković M. (2014): Chemical composition, antimicrobial, antioxidant and antitumor activity of Thymus serpyllum L., Thymus algeriensis Boiss. \& Reut and Thymus vulgaris L. essential oils. Ind Crops Prod, 53: $183-190$.

24. Burt S. (2004): Essential oils: their antibacterial properties and potential applications in foods - a review. Int J Food Microbiol, 94(3): 223-253.

25. Soković M., Glamočlija J., Ćirić A. Kataranovski D., Marin P.D. Vukojević J., Brkić D. (2012): Antifungal activity of the essential oils and components in vitro and in vivo on experimentally induced dermatomycoses at rats. Dig J Nanomater Biostruct, 7(3): 959-966. 


\title{
OSETLJIVOST REFERENTNIH SOJEVA I ORALNIH KLINIČKIH IZOLATA CANDIDA SPP. NA ODABRANA ETARSKA ULJA FAMILIJE $A P I A C E A E$
}

\author{
Miloš Nikolić ${ }^{1}$, Tatjana Markovic ${ }^{2}$, Ana Ćirić ${ }^{1}$, Jasmina Glamočlija ${ }^{1}$, \\ Dejan Marković ${ }^{3}$, Marina Soković ${ }^{1}$ \\ ${ }^{1}$ Institut za biološka istraživanja "Siniša Stanković", Univerzitet u Belgradu, Bulevar \\ Despota Stefana 142, 11000 Beograd, Srbija \\ 2 Institut za proučavanje lekovitog bilja”Josif Pančić”, Tadeuša Košćuška 2, 11000 \\ Beograd, Srbija \\ 3 Stomatološki fakultet, Klinika za dečju i preventivnu stomatologiju, Univerzitet u \\ Beogradu, dr Subotića 8, 11000 Beograd, Srbija.
}

\section{IZVOD}

Cilj ovog istraživanja bio je da se ispita hemijski sastav i antifungalna aktivnost četiri etarska ulja familije Apiaceae, Pastinaca sativa, Foeniculum vulgare, Pimpinella anisum i Anethum graveolens, na referentne sojeve i kliničke izolate Candida spp. iz usne duplje ljudi. Hemijska analiza ispitivanih etarskih ulja (GC-FID i GC/MS) je pokazala da u uljima dominiraju sledeće hemijske klase: u ulju A. graveolens - monoterpenski ugljovodonici $(49,4 \%)$ i glavni sastojak je karvon $(42,2 \%)$ : dok u uljima $P$. anisum $F$. vulgare $P$. sativa većina jedinjenja pripada fenilpropenima $(80,9 \%, 65,9 \%$ i $49,4 \%$, respektivno): pri čemu su glavne komponente prva dva ulja trans-anetol (65,1\% i $80.8 \%$ ): a trećeg, miristicin (49.0 $\%$ ). Minimalne inhibitorne (MIC) i minimalne fungicidne koncentracije ulja (MFC) su određene primenom mikrodilucione metode. Ispitivana tri ulja su inhibirala rast svih Candida spp.; najjaču antifungalnu aktivnost je pokazalo ulje A. graveolens (MIC 0.63-2.5 mg ml${ }^{-1}$; MFC 1.25-5 mg ml${ }^{-1}$ ). Pored česte primene paškanata, morača, anisa i mirođije u tradicionalnoj medicini, ova studija potvrđuje upotrebu njihovih etarskih ulja u tretmanima redukcije i eliminisanju populacije Candida spp. kod humanih pacijenata sa gljivičnim infekcijama.

Ključne reči: Apiaceae, etarska ulja, Candida spp., antifungalna aktivnost. 